\author{
Professor Monica ROMAN, PhD \\ E-mail: monica.roman@csie.ase.ro \\ Lecturer Claudiu VINȚE, PhD \\ E-mail:claudiu.vinte@ie.ase.ro \\ Iris ALEXE, PhD Candidate \\ E-mail: alexeirisa@gmail.com \\ The Bucharest University of Economic Studies
}

\title{
RELIGIOUS BELIEFS AND MIGRATION INTENTIONS AMONG BALKAN YOUTH: A MULTIPLE CORRESPONDENCE ANALYSIS ${ }^{1}$
}

\begin{abstract}
Emigration has been affecting Balkan countries in various ways over the past decades, particularly with the regard to the more mobile young population. Our research aims at studying new cultural determinants of the youth intention to migrate and has been conducted on a survey-based data provided by Friedrich Ebert Stiftung (FES) for Romania, Bulgaria, Bosnia-Herzegovina and Croatia. This paper focuses on specific set of factors, like religious beliefs and practices, which turned out to affect differently the motivation of young individuals from the studied countries to migrate. Employing multiple correspondence analysis in $R$, we were able to identify the association between religious beliefs and the strength of youth intentions to migrate. The results emphasize the overall small role of religious beliefs and fine differences among the studied populations.
\end{abstract}

Keywords: Multiple correspondence analysis, Youth migration, Religion

\section{JEL Classification: R23, J61, J68}

\section{Introduction}

Migration is a phenomenon that affects various geographic regions and every social category, having a significant influence on the demographic development of sending and receiving countries and the functioning of the national labour markets. Balkan countries are characterized as sending countries, since the net migration rates are negative; Some of these countries, such as Romania and

\footnotetext{
${ }^{1}$ A version of this paper was presented at The 5th International Conference The Use of $R$ in Official Statistics, organized by The National Institute for Statistics in November 2017 in Bucharest. We are grateful to the participants for their comments and suggestions. We thank FES Bucharest for their support and the participants in EDURES Master Programme from Bucharest University of Economic Studies for their suggestions.
}

DOI: 10.24818/18423264/54.1.20.06 
Bulgaria are the exponents of new massive emigration flows during the last three decades. For instance, the emigration of working age Romanians has determined significant changes in the demographic structure, family status and reproductive behaviour, with important consequences: a decline of the population and an aging process, resulting in a higher forecast rate of dependence (Roman et al, 2012). Since emigration from Balkan countries seems to be rather permanent, and because people are leaving at early ages, if the situation does not reverse, the effects on the internally available workforce will be lasting.

The first steps towards a firm decision to migrate are taken at early ages and the desire to migrate appears at teenagers related to study or to working abroad, but also to other purposes such as volunteer work (Hemming et al., 2019).Understanding the youth intentions to migrate is important for decision makers, as youth is a valuable resource for any nation and a pillar for a sustainable development (Roman and Paraschiv, 2019). The topic is also relevant for academics, as the determinants for migration decision at early ages still need to be revealed. Among these factors, cultural traits and religiosity are the least studied. The scientific interest in explaining youth mobility in Europe is recently increasing and European countries and also European Union strongly support the research of the factors, benefits and risks associated with youth mobility, through a number of projects and research grants ${ }^{2}$.

Balkan Peninsula is a region characterized by significant differences between countries in terms of population structure and socio-economic development. Although sharing common historical patterns, the Balkan countries faced recent migration movements in various ways. Some of the former communist countries are now EU members and their nationals enjoy the opportunity to work and travel all over Europe with no restriction (Slovenia, Romania and Bulgaria, and Croatia), while other countries still face barriers (Bosnia-Herzegovina, Serbia, Albania, Montenegro, Kosovo, Macedonia), as non-EU members. Greece is the only country in Balkans with no communist background, being the oldest EU member state in the region. Religious structure of the Balkan population could not be more diverse: for centuries, orthodox, Catholics, Muslims and other religious denominations share the same geographical space. Out of these countries, we have selected the four countries in our sample based on data availability and on the variability of religious structures in order to capture population of different religious denominations. Romanian and Bulgaria are countries with large Christian orthodox communities, Croatia is a catholic country, while Bosnia-Herzegovina has a mixed religious structure; therefore, the sample presents different population structures in terms of religious denominations that makes it suitable for our research purposes.

\footnotetext{
${ }^{2}$ Projects such as MOVE or YMobility are examples of research financed through H2020 program for the study of youth migration and mobility in Europe.
} 
Religious Beliefs and Migration Intentions among Balkan Youth: A Multiple Correspondence Analysis

The paper aims at bringing into attention some less explored factors that influence the intentions of Balkan youth to migrate. We intend to focus on factors related to religious beliefs and practices, which turned out to impact differently the motivation to migrate of young individuals from the studied countries. Our research hypothesis is that religious denomination and practices impact the desire to migrate in the case of Balkan youth. Another element of novelty is that we observe a specific type of migrants, namely the young migrants aged 15-29, a group of high importance for any society, as they have the highest willingness to migrants. We compare the religious feelings and the intentions to migrate of groups of young migrants from different countries and having different religious beliefs.

We use recent data collected by Friedrich-Ebert-Stiftung (FES) between 2011 and 2015 in nine Balkan countries. The survey was conducted in 2014 for the three countries described in this research (Bosnia-Herzegovina, Bulgaria and Romania) and in 2012 in Croatia, as the fourth country of interest. The dataset was analysed using multiple correspondence analysis (MCA)and R programming.

The structure of the paper is the following: in Section 2 a brief literature review of the topic is presented, while in Section 3 the data set is described. Section 4 is dedicated to briefly presenting the specific methodology, MCA. The results of the analysis are explained in section 5, while the conclusions are drawn in the last section.

\section{Literature Review}

The association between migration and religion is well debated in the social and economic literature, mainly from the perspective of understanding religiosity of individual migrants at destination.

Therefore, Connor (2008) uses in his article a longitudinal dataset from Quebec (Canada) on 1,000 immigrants during the 1990s. Results indicate that immigrant religious participation decreases substantially as compared to the average level of religious participation among the same immigrants prior to their migration.

The religious context at destination is extremely relevant in explaining migrants' religiosity. Based on standardized 20 existing surveys on immigrants in eight Western countries, (covering about 38,000 immigrants) and applying multilevel models, Van Tubergen (2006) comes to an important result: immigrants from countries with higher levels of modernization express lower levels of religious commitment; Also, immigrants living in religious countries are more religious themselves. Van Tubergen (2007) proved that stronger social integration in Dutch society would diminish the religiosity of immigrants He used three religious variables: affiliation, attitudes, and attendance, while the study used large-scale surveys of four immigrant groups (Turks, Moroccans, Surinamese and

DOI: $10.24818 / 18423264 / 54.1 .20 .06$ 
Dutch Antilleans) in the Netherlands in 1998 and 2002. The author concludes that integration in a secular society decreases migrants' religiosity. In the same line, Phillip Connor concluded in a paper published in 2010 that less welcoming immigrant contexts are associated with higher religious outcomes among Muslim immigrants in comparison to the host region's religiosity.

Other researchers identified the causes and the factors that explain the differences in migrants' religiosity at destination. Van Tubergen and Sindradottir (2011) used the European Social Survey data (2002-2008) from more than 10,000 first generation immigrants living in 27 receiving countries. They looked at economic status and education of migrants and found that on the individual level, religiosity is higher among immigrants who are unemployed, less educated, and who have recently arrived in the host country. One important result is that on the contextual level, the religiosity of natives positively affects immigrant religiosity.

There is also interest for explaining the effects of migrants' religiosity. Goschin and Roman (2010) using the results of a survey among more than 1500 Romanian international migrants of different religious faiths, improve the understanding of the economic performance in a migration context. Economic performance was analysed based on economic status, income and remittances sent home, and neo-protestants, and people belonging to orthodox and catholic denominations perform better than the reference category, which was "no religion". In their recent, large study, Doquier et al. (2017), using Gallup World Poll data on individual opinions and beliefs, migration aspirations, short-run migration plans, and preferred destination choices proved that individuals who intend to emigrate to OECD, high-income countries exhibit significantly lower levels of religiosity than the rest of the population. They also share more genderegalitarian views, although the effect only holds among the young (aged 15 to 30), among single women, and in countries with a Sunni minority.

Most studies on migration do not usually concentrate on children and adolescents unless they relate to adolescents as victims of trafficking or abuse in various forms (Tienda and Taylor, 2007).

It is important to mention that there is a significant body of literature analysing the impact of age and life stages on religiosity. The general idea advanced in the religion literature is that people's religiosity increases with age. Stark and Bainbridge (1987) provide a first potential explanation: at a higher age, people have stronger fears of death, and religion may therefore become more important in providing the promise of an afterlife. Therefore, it is not expected to find high religiosity among youth. However, Balkan countries proved to be an interesting case, as the countries have different religious denominations and it seems that young population is still practicing religious. The literature on youth intentions to migrate in relation to their religious believes is however limited.

Hoffman, Marsiglia and Ayers (2015) based on a survey among students enrolled in an alternative high school program located in the state of Guanajuato, 
Religious Beliefs and Migration Intentions among Balkan Youth: A Multiple Correspondence Analysis

(Mexico) argue that as external religiosity increases, the desire to work or live in the USA decreases. Furthermore, as internal religiosity increases, the desire to work or live in the USA and plans to migrate increase. Falco and Rotondi (2015) have identified a positive relationship between Internet use and individual-level willingness to migrate, while there exists a negative relationship between political Islam and individual-level willingness to migrate. In Portugal Silva and Neto (1993) identified the predictive factors for adolescents' intention to migrate. The results indicated that the most important factors are the attitude towards migration, connections with other migrants and family attachment.

In Slovakia, Orosova et al. (2018) used binary logistic regression to analyse the data obtained from 375 university students. The results showed that personal normative beliefs and desire for change were significantly positively associated with emigration intentions. Moreover, Sanduet al. (2015) proved that there are similarities between youth in various European countries: such similarities exist between Romanian youth and youth from Latvia and Slovakia in respect to their intention to migrate. The similarities are explained by the migratory context, all the three countries being countries of net migration. Roman and Vasilescu (2016) analysed the age differences in Romanian youth intentions to migrate and found that that age is a relevant factor for the intention of the youth to migrate: the younger a person is, the higher the probability of wanting to emigrate. Moreover, when looking at young adults, the use of internet and the goal setting for a future abroad are the key factors that significantly determine the migration intentions, rather than economically related factors. Plopeanu and colleagues (2018) empirically show that motivations and attitudes towards a meritocratic environment for professional advancement, and individual freedom are positive key factors for students' migration intentions after graduation. In addition, they emphasized the significant role of religiosity and intergenerational transfer of parental migration experience on Romanian students' decision to migrate.

The literature on explaining the effect of religious factors on youth intensions to migrate is still quite limited and our research tries to fill this gap by addressing this topic for the case of Balkan youth.

\section{The data set and the variables}

The data used in this study comes from a quantitative research conducted by Friedrich-Ebert-Stiftung (FES), namely "FES youth studies in East Europe"(YEE). Studies from nine countries (Albania (2011), Bosnia and Herzegovina (2014), Bulgaria (2014), Croatia (2012), Kosovo (2012), Macedonia (2013), Romania (2014), Slovenia (2013) and Serbia (2015)) are a part of a crossnational research that investigate key common issues, providing insight into the lives, attitudes and practices of youth from Balkans. YEE surveys have a common core with the following themes included in the questionnaires: leisure and lifestyle;

DOI: $10.24818 / 18423264 / 54.1 .20 .06$ 
religion and social affiliations; family and friends; concerns and aspirations; education and employment; democracy and politics; governance and development; national and world politics; demographic module. The four countries included in our research cover more than 4800 respondents; the youth sample was stratified by size of county and place of residence and by age and gender. ${ }^{3}$

In Bosnia-Herzegovina data collection was completed in the second half of 2014 among a representative sample of 1004 adults, of which 48,5\% women and $51,5 \%$ men, in the 15-27 age group, with average age of 21 years. Total sample of respondents was divided into three age groups: $15-17$ years $(21,5 \%), 18-22$ years (39\%), and 23-27 years (39,5\%). The study involved respondents from all over Bosnia and Herzegovina, with 45,2\% respondents from rural settlements, and $54,8 \%$ from urban settlements, providing "unquestionable reliability of the collected indicators" (Žiga et al., 2015).

In Bulgaria the representative survey used a two-stage cluster sample (206 clusters) stratified by region (28 regions) and type of settlement (capital city, regional centre, small town, and village) based on a systematic random sample of polling districts in Bulgaria. The final sample includes 1030 respondents (Mitev and Kovacheva, 2014). The distribution of the respondents by religion show that the majority - three-quarters - of Bulgarian youth identify themselves as Christian, $16 \%$ as Muslim, $1 \%$ as followers of other religions, and a total of $9 \%$ as nonreligious or atheists and agnostics (Mitev and Kovacheva, 2014).

In Croatia the representative sample encompassed 1500 respondents between 14 and 27 years of age (born between 1985 and 1998) from all over Croatia. CAPI methodology was used, with individual interviews of about 45 minutes on average (Ilišin et al., 2013).

In Romania the sample used was random, stratified, with proportional allocation of respondents. The sampling universe was the resident population of non-institutionalized Romanian aged between 15 and 29 years andthe timeline of the interviews was 19 to 31 July, 2014.The initial database contains 1302 Romanian respondents(Umbreş, Sandu and Stoica, 2014).After eliminating those who did not answer the question regarding the intention to emigrate, we obtained a sample of 1269 young people, out of which 443 are teenagers aged 15 to 19 years.

The variables related to religion and also those related to intentions to migrate are common in all the four questionnaires. These variables measure two dimensions of religiosity: religion beliefs and religious practices.

The set of explanatory variables includes: Religious confession (Christian, Muslim, Other, No religion or Atheists), as a nominal variable.

The religious practice is captured by the following ordinal variables:

- Frequency of going to church / mosque / synagogue to attend a religious service, with the variants: Regularly, Often, Sometimes, Never;

\footnotetext{
${ }^{3}$ For more details, see https://www.fes.de/en/youth-studies/
} 
Religious Beliefs and Migration Intentions among Balkan Youth: A Multiple Correspondence Analysis

- Frequency of celebrating religious holidays, with the variants: Regularly, Often, Sometimes, Never.

The intention to migrate is assessed with the following question: "How strong is your desire to leave the country?", and the possible answers are: Very strong, Much, Some, None.

Table 1. The distribution of respondents on variables and countries

$\begin{array}{ccccccc}\begin{array}{c}\text { Observed } \\ \text { Variable }\end{array} & \text { Value } & \begin{array}{c}\text { Bosnia - } \\ \text { Herzegovina }\end{array} & \begin{array}{c}\text { Bulgaria } \\ (\%)\end{array} & \begin{array}{c}\text { Croatia } \\ (\%)\end{array} & \begin{array}{c}\text { Romania } \\ (\%)\end{array} & \begin{array}{c}\text { Balkan } \\ (\%)\end{array}\end{array}$

(\%)

\begin{tabular}{|c|c|c|c|c|c|c|}
\hline \multirow{4}{*}{$\begin{array}{l}\text { Religious } \\
\text { confession }\end{array}$} & Christian & 39.74 & 74.07 & 89.53 & 97.77 & 78.13 \\
\hline & Muslim & 55.78 & 15.52 & 0.47 & 0.15 & 15.07 \\
\hline & Other & 0.10 & 0.69 & 2.53 & 0.08 & 0.97 \\
\hline & No religion & 4.38 & 9.72 & 7.47 & 2.00 & 5.83 \\
\hline \multirow{4}{*}{$\begin{array}{l}\text { Frequency } \\
\text { of going to } \\
\text { church or } \\
\text { attending } \\
\text { Mass }\end{array}$} & Regularly & 13.15 & 5.21 & 9.07 & 7.60 & 8.71 \\
\hline & Often & 19.82 & 11.20 & 14.47 & 16.97 & 15.57 \\
\hline & Sometimes & 56.27 & 63.46 & 53.07 & 44.70 & 53.67 \\
\hline & Never & 10.76 & 20.14 & 23.40 & 30.72 & 22.06 \\
\hline \multirow{4}{*}{$\begin{array}{l}\text { Frequency } \\
\text { of } \\
\text { celebrating } \\
\text { religious } \\
\text { holidays } \\
\end{array}$} & Regularly & 72.61 & 40.18 & 63.80 & 23.04 & 49.65 \\
\hline & Often & 15.54 & 24.95 & 16.60 & 37.02 & 23.65 \\
\hline & Sometimes & 9.56 & 18.66 & 11.27 & 24.73 & 16.11 \\
\hline & Never & 2.29 & 16.21 & 8.33 & 15.21 & 10.59 \\
\hline \multirow{5}{*}{$\begin{array}{l}\text { The } \\
\text { intention to } \\
\text { emigrate }\end{array}$} & Very & & & & & \\
\hline & Strong & 23.71 & 6.68 & 7.27 & 17.13 & 13.23 \\
\hline & Much & 22.01 & 24.46 & 19.20 & 22.73 & 21.85 \\
\hline & Some & 3.09 & 29.17 & 32.07 & 21.35 & 22.53 \\
\hline & None & 51.20 & 39.69 & 41.47 & 38.79 & 42.39 \\
\hline Sample size & & 1004 & 1018 & 1500 & 1302 & 4824 \\
\hline
\end{tabular}

Worth mentioning that as a result of the data tests conducted during the research, we excluded the variables recording the Frequency of praying and Having confession, since it turned out that these practices differ across countries and religious denominations.

Table 1 presents the percentage distribution of respondents according to the variables of interest for the Balkan's region and for the selected countries. The respondents with the strongest intention to emigrate are those from BosniaHerzegovina and Romania, while the other two countries seem to present more a moderate desire for going abroad. Interestingly, the respondents from Bosnia also

DOI: $10.24818 / 18423264 / 54.1 .20 .06$ 
have the largest intention to stay in the country. The youth from BosniaHerzegovina seem to experience most intense the religious practices, while Romanians seem to be the least inclined for practicing religion.

\section{The research methodology and the data analysis method}

The values of the exploratory variables collected from the questionnaires are of categorical type, some of them nominal, as is the case with Religious confession, and others are ordinal, like Frequency of going to church / mosque / synagogue, Frequency of celebrating religious holidays and Desire to leave the country. In order to determine how such observed variables are together at work in connection with the intention to migrate, we employed Multiple Correspondence Analysis(MCA)as method to create new perspectives (dimensions) upon the initial data samples. MCA, developed by the French statistician Jean Paul Benzécriin 1973, is a descriptive exploratory technique designed to analysis multi-way tables containing some measure of correspondence between the rows and columns. The results provide information which is similar in nature to those produced by Factor Analysis, and they allow for exploring the structure of categorical variables included in the table.

MCA may be defined as a special case of Principal Component Analysis (PCA). Cross-tabulation groups variables to understand the correlation between different variables. However, MCA and PCA are used under different circumstances: PCA is used for tables consisting of continuous measurement, whereas MCA is applied to contingency tables (i.e. cross-tabulations). Its primary goal is to transform a table of numerical information into a graphical display, in which each row and each column is depicted as a point.In MCA, the cloud of profile points has weights (masses) adding up to 1 . These points have a centroid and a distance, (known as Chi-square distance, a version of Euclidian distance) between profile points, used for computing the point inertia. Each profile point has a specific contribution to the inertia of the whole cloud. Inertia is further used and decomposed for developing a smaller number of dimensions, for a lower dimensional representation of the variables and an easier graphical description.

The main advantage of MCA is that it allows for a suggestive, intuitive graphical representation of the variables and also for a dual display in which row and column geometries have similar interpretations, for an easier analysis and identification of the possible relationships (Greenacre and Primicerio, 2014). Also, if the number of variables (rows and columns) is too large, the plots interpretation can be difficult.

The analysis included an initial phase of data pre-processing and data cleaning, which consisted in: selecting from the datasets only the variables of interest for our study; substituting the numerical values recorded from the questionnaires with corresponding nominal or ordinal values; concatenating the 
Religious Beliefs and Migration Intentions among Balkan Youth: A Multiple Correspondence Analysis

values for the selected variables from Bosnia-Herzegovina, Bulgaria, Croatia and Romania in order to obtain the perspective for the Balkan's region.

The $\mathrm{R}$ packages used in the research are as follows: FactoMineR package MCA function; MASS package - mca function; and ggplot2 package - ggplot function (an implementation of the Grammar of Graphics).We conducted the research driven by the goal of obtaining a visually suggestive and conclusive outcome (Dârdală, Furtună and Ioniță, 2017).

\section{Results and discussion}

Our research goes through two layers of aggregation, in a top-down fashion, briefly described in this section. We start by observing the values describing the religious beliefs and practices characterizing the observations from all four Balkan's countries studied: Bosnia-Herzegovina, Bulgaria, Croatia and Romania, 4824 subjects in total.

\subsection{Results for the entire sample from four Balkan countries}

Table 2 shows, for each new dimension created through MCA the eigenvalue, the percentage of the explained variance, and the cumulative percentage of the explained variance resulted with each additional dimension.

Table 2. Eigen values of the MCA model for the Balkan's region

\begin{tabular}{lrrr}
\hline $\begin{array}{l}\text { MCA new } \\
\text { dimensions }\end{array}$ & Eigenvalue & $\begin{array}{r}\text { Percentage of } \\
\text { variance }\end{array}$ & $\begin{array}{r}\text { Cumulative percentage } \\
\text { of variance }\end{array}$ \\
\hline Dim 1 & 0.44314 & $\mathbf{1 4 . 7 7 1 3 2}$ & $\mathbf{1 4 . 7 7 1 3 2}$ \\
\hline Dim 2 & 0.31442 & $\mathbf{1 0 . 4 8 0 6 4}$ & $\mathbf{2 5 . 2 5 1 9 6}$ \\
\hline Dim 3 & 0.28876 & $\mathbf{9 . 6 2 5 2 0}$ & $\mathbf{3 4 . 8 7 7 1 6}$ \\
\hline Dim 4 & 0.27544 & $\mathbf{9 . 1 8 1 3 3}$ & $\mathbf{4 4 . 0 5 8 4 9}$ \\
\hline Dim 5 & 0.25638 & 8.54607 & 52.60456 \\
\hline Dim 6 & 0.25042 & 8.34733 & 60.95189 \\
\hline Dim 7 & 0.24800 & 8.26681 & 69.21870 \\
\hline Dim 8 & 0.21826 & 7.27524 & 76.49394 \\
\hline Dim 9 & 0.21452 & 7.15074 & 83.64468 \\
\hline Dim 10 & 0.19045 & 6.34832 & 89.99300 \\
\hline Dim 11 & 0.17329 & 5.77632 & 95.76932 \\
\hline Dim 12 & 0.12692 & 4.23068 & 100.00000 \\
\hline & & & \\
\hline
\end{tabular}

It has to be emphasized that the eigenvalues are relatively small giving the indication that there is not a decisive correlation between the religious aspects observed and the intention to leave the region as a whole. In addition to that, the

DOI: $10.24818 / 18423264 / 54.1 .20 .06$ 
Monica Roman, ClaudiuVințe, Iris Alexe

first 4 dimensions explain about $44 \%$ of the entire variance of the model, and each have comparable contributions (see the highlighted cells in Table 2).

At a further investigation, studying the coordinates of the cross-tabulated causal variables' values in the MCA discovered dimensions, it has to be noticed that the first MCA discovered variable receives most of the contributions from values of the causal variables: No Religion, Church Never, Holidays Never and Strong intention to leave the country (Table 3 ). It essentially emphasizes the fact that, even if the Balkan's youth did not show connecting the religious beliefs with the intention to emigrate, the lack of any religious implication imply a predisposition to be rather inclined to leave the country. Those subjects appear to not be connected to the local community's traditions and more predispose to leave the place.

Table 3. The coordinates in the MCA dimensions for the Balkan's region

\begin{tabular}{llrrrr}
\hline Variable & Value & Dim.1 & Dim.2 & \multicolumn{1}{l}{ Dim.3 } & \multicolumn{1}{c}{ Dim.4 } \\
\hline Religion & Christian & & & & \\
\hline Religion & Muslim & -0.122 & -0.243 & -0.192 & -0.207 \\
\hline Religion & Other & -0.494 & 1.115 & 0.963 & 0.985 \\
\hline Religion & No Religion & 1.384 & -0.822 & -0.111 & 0.835 \\
\hline & & 2.685 & 0.515 & 0.104 & 0.089 \\
\hline Church & Church_Regularly & -0.770 & 1.713 & -0.561 & -1.623 \\
\hline Church & Church_Often & -0.590 & 0.195 & -1.110 & 1.224 \\
\hline Church & Church_Sometimes & -0.316 & -0.435 & 0.444 & -0.117 \\
\hline Church & Church_Never & 1.490 & 0.245 & -0.075 & 0.061 \\
\hline & & & & & \\
\hline Holidays & Holidays_Regularly & -0.489 & 0.590 & -0.068 & -0.236 \\
\hline Holidays & Holidays_Often & -0.084 & -0.764 & -0.562 & 0.938 \\
\hline Holidays & Holidays_Sometimes & 0.208 & -1.059 & 1.260 & -0.577 \\
\hline Holidays & Holidays_Never & 2.164 & 0.551 & -0.340 & -0.110 \\
\hline & & & & & \\
\hline Emigration & Strong & 0.193 & 0.613 & 0.909 & 0.523 \\
\hline Emigration & Some & 0.029 & -0.457 & -0.915 & -0.668 \\
\hline Emigration & Much & 0.093 & -0.090 & 0.008 & -0.013 \\
\hline Emigration & None & -0.124 & 0.098 & 0.199 & 0.199 \\
\hline & & & &
\end{tabular}


Religious Beliefs and Migration Intentions among Balkan Youth: A Multiple Correspondence Analysis

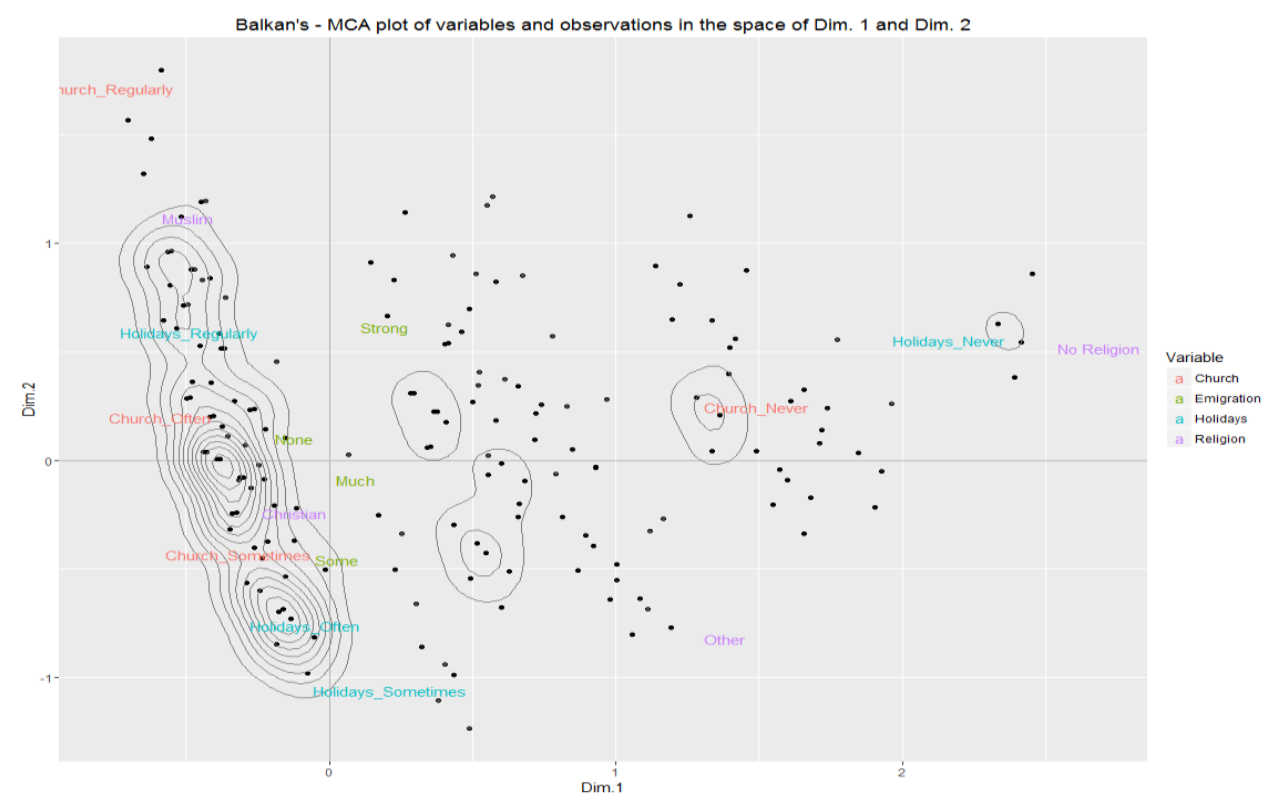

Figure 1. Balkan's - causal variables and observations in the space of MCA Dim. 1 and Dim. 2

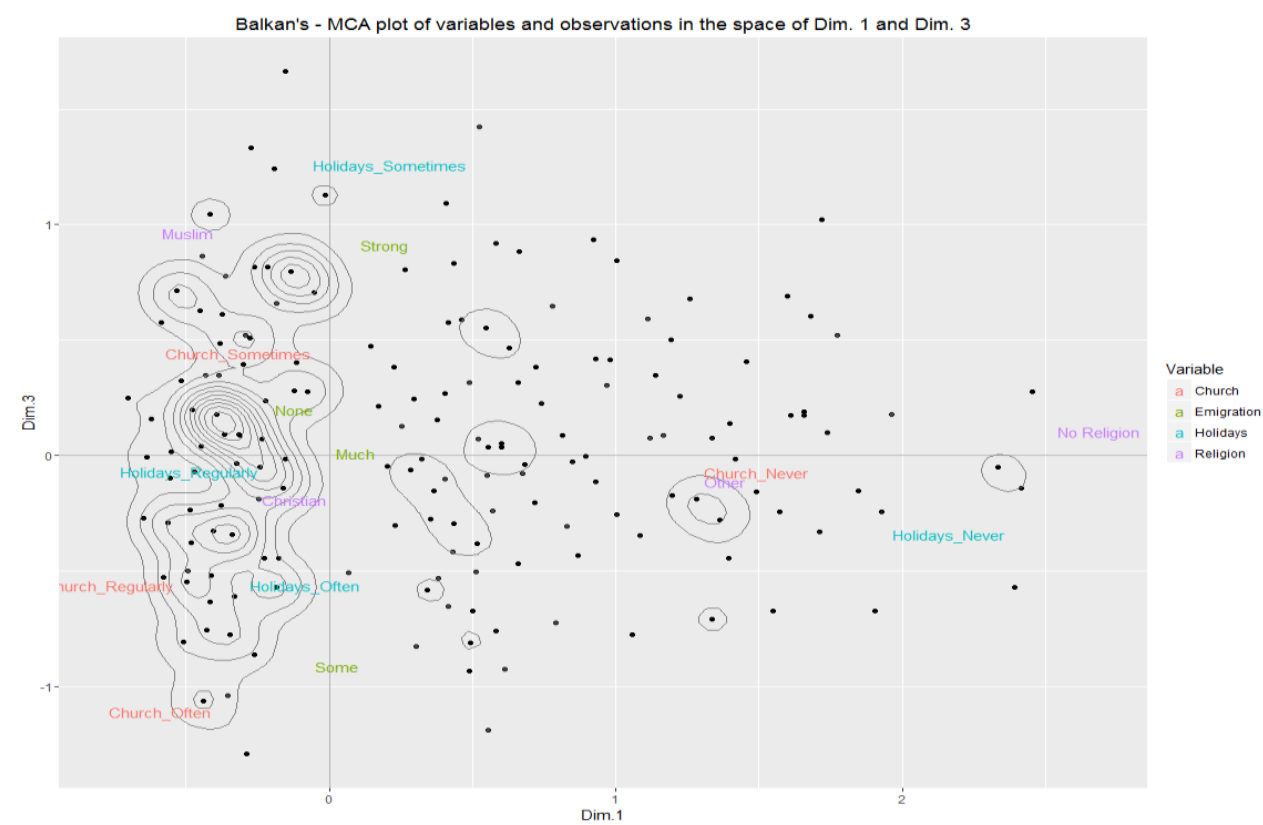

Figure 2. Balkan's - causal variables and observations in the space of MCA Dim. 1 and Dim. 3

Figure 1 and Figure 2 offer the graphical support to this observation. In addition to that, the third MCA dimension (see the values highlighted for Dim. 3 in 
Table 3) shows that the respondents of Muslim confession, along with values for going to church/mosque/synagogue sometimes and celebrating the religious holidays sometimes appear to have a strong intention to emigrate. Figure 2 offers the graphical support for the latter described connection.

\subsection{Cross-countries comparative approach}

On the second layer, the analysis was separately conducted for each country, as the religious intensity is differently affected by national context. We have measured the intensity of the association between the religious beliefs and practice, along with the intention to migration. Similar analysis was run for each of the countries in the sample.

Figures 3, 4, 5, and 6 show the coordinates of the causal variables studied, in the space of the first two MCA dimensions determined for each country. For Bulgaria, Croatia and Romania the intention to emigrate appears less correlated with the religious confession, but rather with lack of implication in religious practice. The case of Bosnia-Herzegovina shows an interesting pattern, as BosniaHerzegovina is a country with two large denominations, Christians and Muslims. It seems that the religious confession has a greater impact on the youth predisposition to emigrate from this country. Figure 7 shows that, in the case of Balkans, irreligious youth and those who do not adhere to any religious group of practice are more inclined to leave the country.

The Bulgarian case appears to show the least intention to emigrate from the whole Balkan's group that we investigated (Figure 4). In Bulgaria, the Muslim community ( $15.52 \%$ in the sample) seems to have a stronger intention to emigrate than the Christians' majority (Figure 9).

The case of Croatia also demonstrates a weak association between intention to migrate and religious beliefs (Figure 5). Croatia has a large Christian majority, and all the other religious confessions, along with irreligious ones show a stronger intention to emigrate than the Christians (Figure 10).

The Romanian case is also interesting, as Romania is one of the countries with the highest emigration in Europe. Romanian youth have a rather strong intention to emigrate, but this is not associated with their religious beliefs (Figure 6). As also shown in Figure 11, the intention to emigrate is not correlated with the religious beliefs. Since $97.77 \%$ respondents in the sample declared themselves as being Christians, most of them going to the church sometimes and celebrating the religious holidays quite consistently (Figure 11) the strong intention to leave the country has to fuelled by other reasons. Nevertheless, in the case of Romania, those who are in communities with well-established tradition regarding the religious practice and holidays' celebration are far less inclined to leave the country. Figure 11 shows convincingly clear that the youth who are involved in the religious

DOI: $10.24818 / 18423264 / 54.1 .20 .06$ 
Religious Beliefs and Migration Intentions among Balkan Youth: A Multiple Correspondence Analysis

practices regularly are more connected with the traditions of the place and less predispose to leave such an environment.

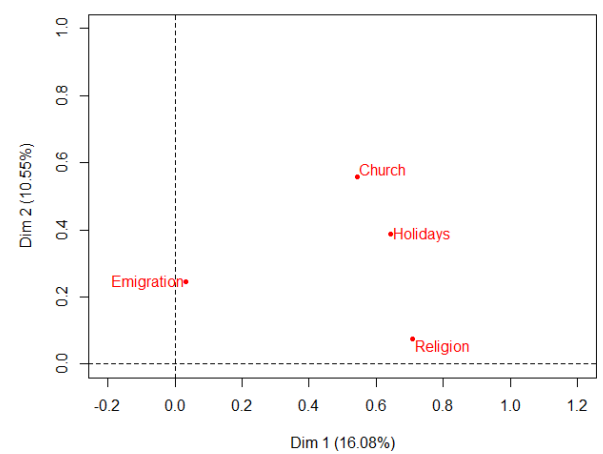

Figure 3. Bosnia-Herzegovina - variables representation

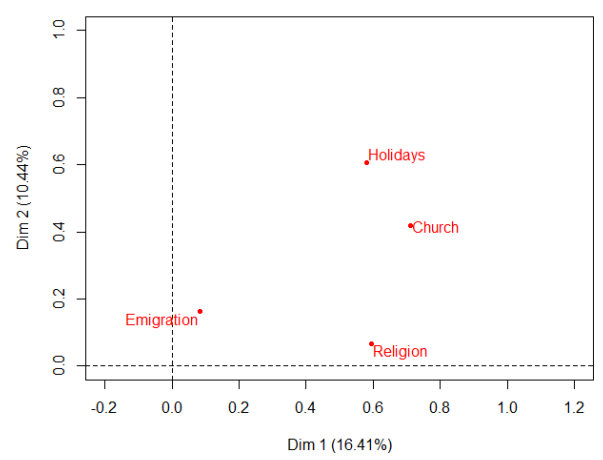

Figure 5. Croatia - variables representation

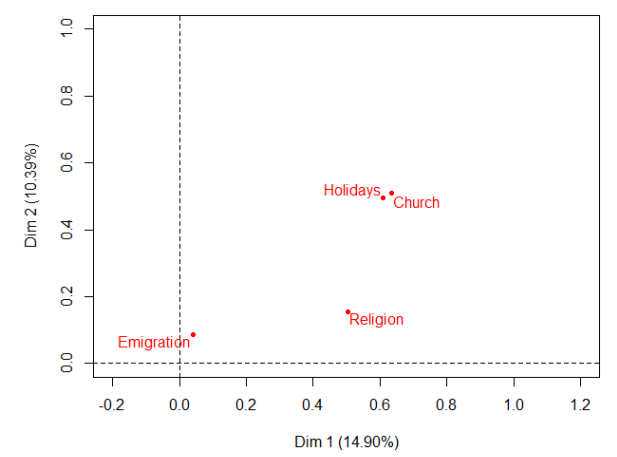

Figure 4. Bulgaria - variables representation

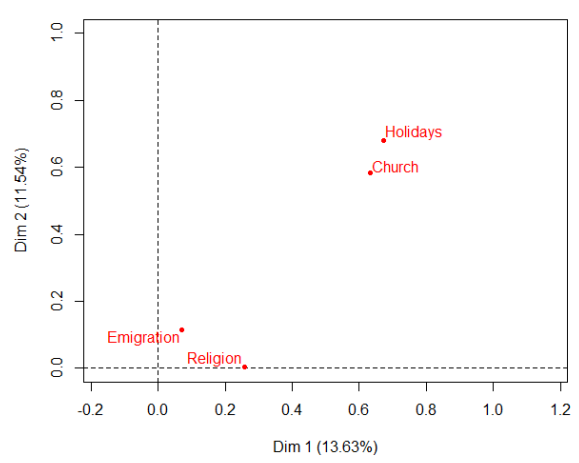

Figure 6. Romania - variables representation

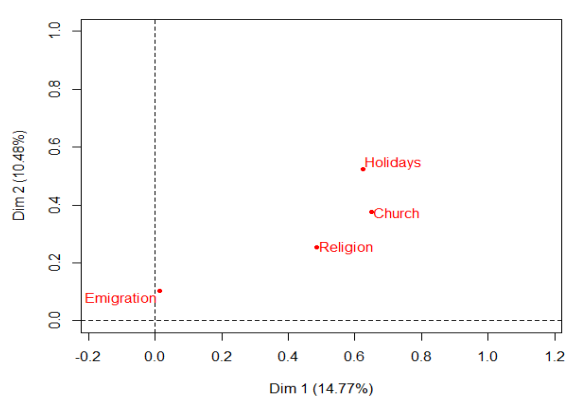


Monica Roman, ClaudiuVințe, Iris Alexe

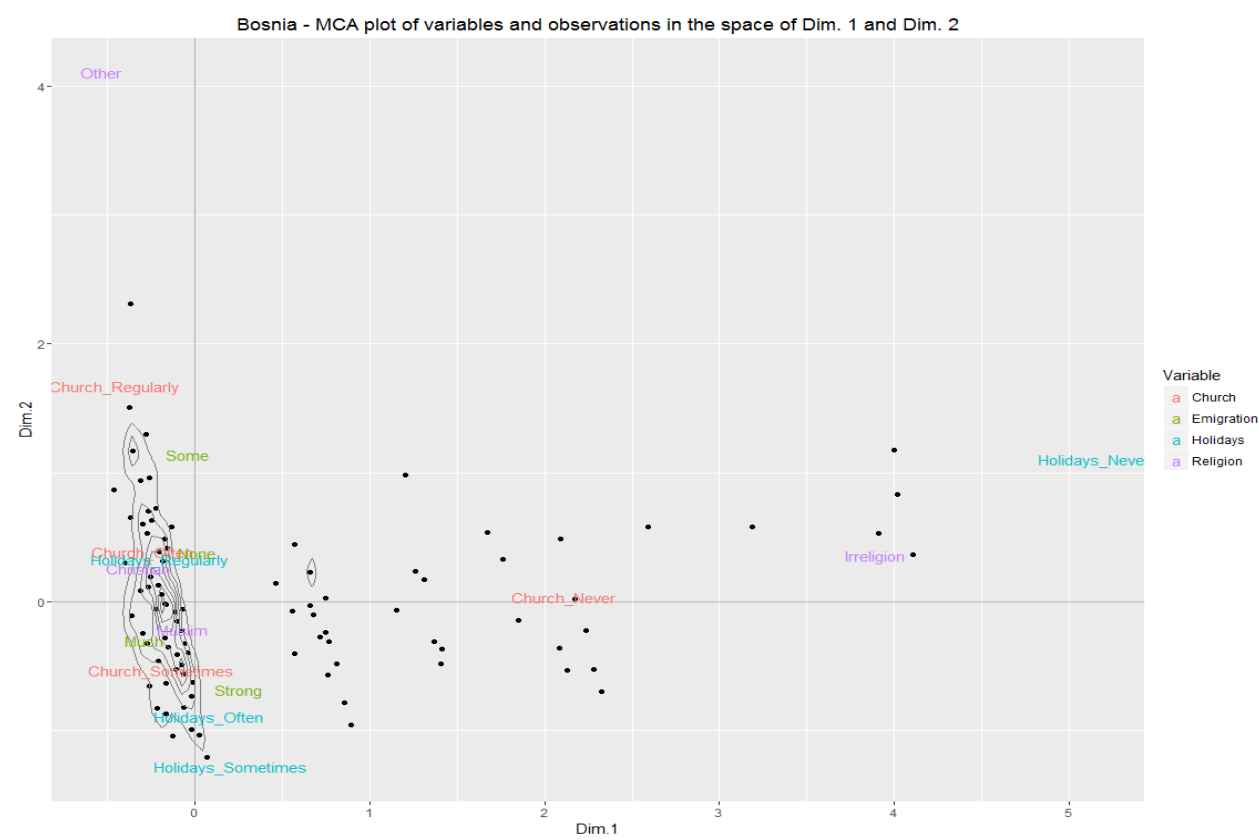

Figure 8. Bosnia-Herzegovina - causal variables and observations in the space of MCA Dim. 1 and Dim. 2

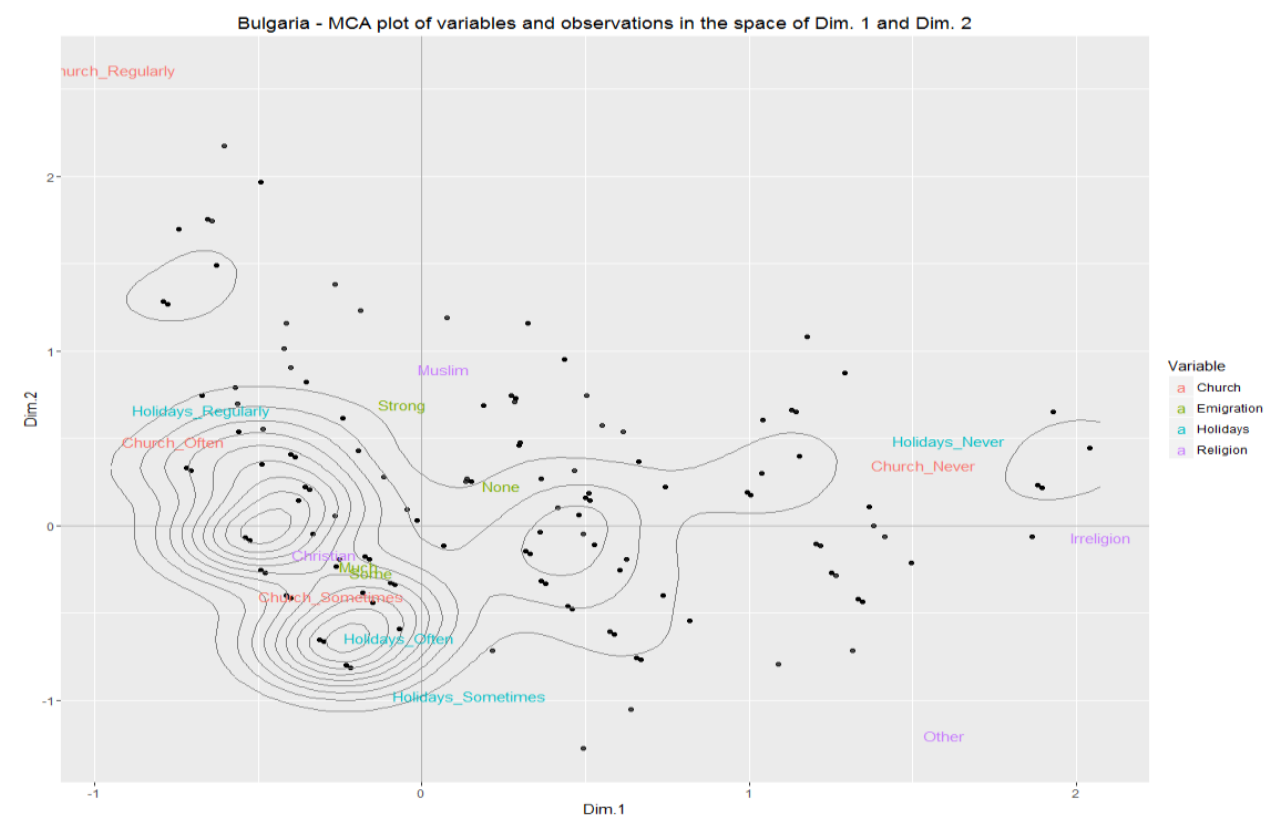

Figure 9. Bulgaria - causal variables and observations in the space of MCA Dim. 1 and Dim. 2 
Religious Beliefs and Migration Intentions among Balkan Youth: A Multiple Correspondence Analysis

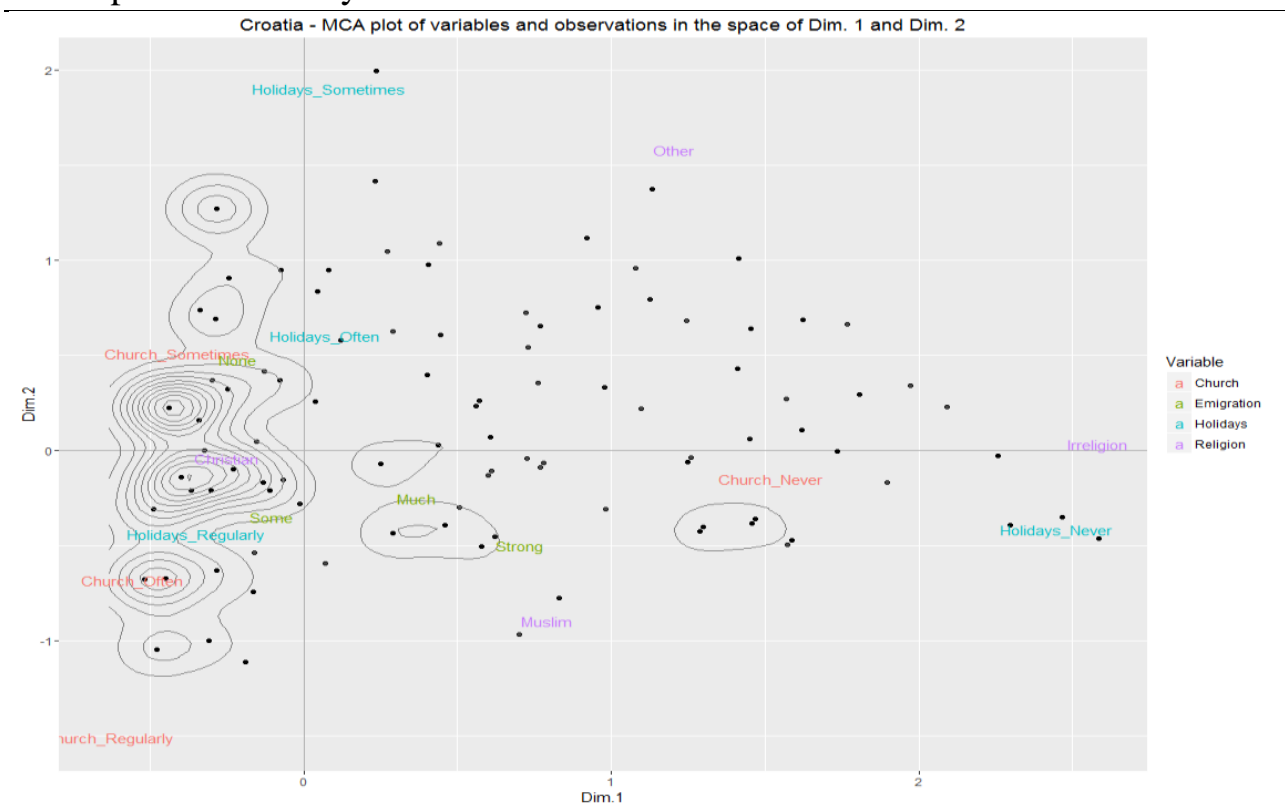

Figure 10. Croatia - causal variables and observations in the space of MCA Dim. 1 and Dim. 2

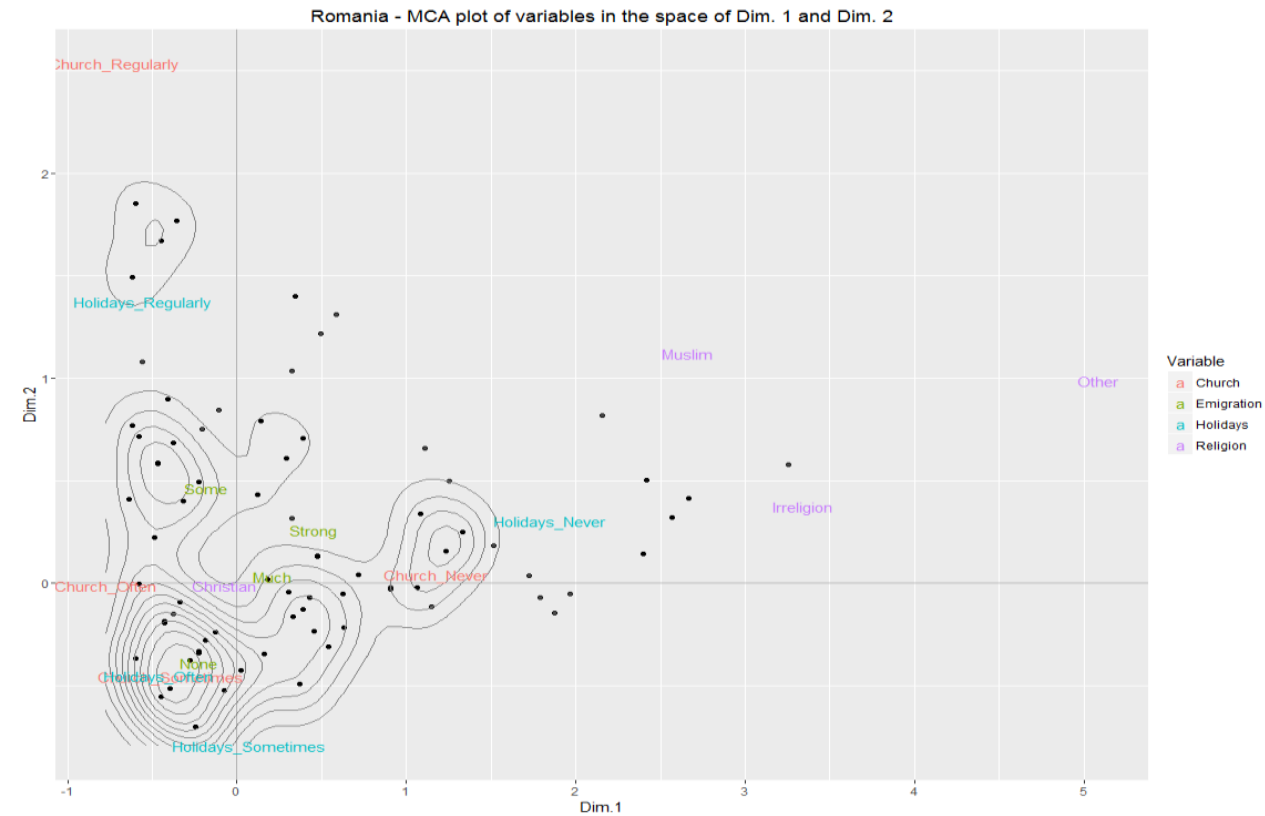

Figure 11. Romania - causal variables and observations in the space of MCA Dim. 1 and Dim. 2

\section{Conclusions}

DOI: 10.24818/18423264/54.1.20.06 
Monica Roman, ClaudiuVințe, Iris Alexe

The Balkan countries are divers in their religious patterns, but have common features related to migrants'behaviour. Most of them are net emigration countries, and the desire to live the country among young generations is high. Using four Balkan countries as a case study, the paper aims at identifying the role of religion in youth intentions to migrate. As the variables of interest are nominal or ordinal, the method of analysis employed was MCA. At the level of Balkan's region, studying the coordinates of the cross-tabulated causal variables' values in the MCA discovered dimensions, we noticed that the first MCA discovered variable receives most the contributions from values of the explanatory variables: No Religion, Church Never, Holidays Never and Strong intention to leave the country.

In the case of Bosnia-Herzegovina, irreligious youth and those who do not adhere to any religious group of practice are more inclined to leave the country. In Bulgaria, the Muslim community seems to have a stronger intention to emigrate than the Christians' majority. Croatia has a large Christian majority, and all the other religious confessions, along with irreligious ones show a stronger intention to emigrate than the Christians. In the case of Romania, the strong intention to emigrate is not correlated with the religious beliefs. Nevertheless, in the case of Romania, those who are in communities with well-established tradition regarding the religious practice and holidays' celebration have no desire to leave the country.

These exploratory, graphic initial results open the path for further research related to the role of cultural traits as determinants of migration intentions. Future confirmatory analysis needs to be conducted, possibly employing statistical methods or econometric modelling, such as ordinal logistic regression model. The research also emphasizes the strengths of the MCA as an intuitive method, powerful in providing visual representation of the association between categorical and ordinal variables.

\section{REFERENCES}

[1] Connor, P. (2008), Increase or Decrease? The Impact of the International Migratory Event on Immigrant Religious Participation. Journal for the scientific study of religion, 47(2): 243-257;

[2] Connor, P. (2010), Contexts of Immigrant Receptivity and Immigrant Religious Outcomes: The Case of Muslims in Western Europe. Ethnic and Racial Studies, 33(3): 376-403;

[3] Dârdală M., Furtună T. F., Ioniță C. (2017),Statistical Methods for Analysing the Relationship Among Ethnic, Religious and Linguistic Diversity In Romania; Economic Computation and Economic Cybernetics Studies and Research; Issue 4/2017, Vol. 51: 37-54, ISSN 0424 - 267 X;

DOI: $10.24818 / 18423264 / 54.1 .20 .06$ 
Religious Beliefs and Migration Intentions among Balkan Youth: A Multiple Correspondence Analysis

[4] Docquier, F., Tansel, A., and Turati, R. (2017), Do Emigrants Self-Select Along Cultural Traits?: Evidence from the MENA Countries. Evidence from the MENA Countries (November 17, 2017);

[5] Falco, C. and Rotondi, V. (2016), Political Islam, Internet Use and Willingness to Migrate: Evidence from the Arab Barometer. Peace Economics, Peace Science and Public Policy, 22(1): 73-95;

[6] Greenacre, M. and Primicerio, R. (2014), Multivariate Analysis of Ecological Data. Fundacion BBVA;

[7] Hemming, K., Schlimbach, T., Tilmann, F., Nienaber, B., Roman, M. \&Skrobanek, J. (2019), Structural Framework Conditions and Individual Motivations for Youth-Mobility: A Macro-Micro Level Approach for Different European Country-Types. Migration Letters, 16(1): 45-59;

[8] Hoffman, S., Marsiglia, F. F. and Ayers, S. L. (2015), Religiosity and Migration Aspirations among Mexican Youth. Journal of international migration and integration, 16(1): 173-186;

[9] Ilišin, V., Bouillet, D., Gvozdanović, A., and Potočnik, D. (2013), Youth in A Time of Crisis: First IDIZ-Friedrich-Ebert-Stiftung Youth Survey [SPSS dataset]. Zagreb: Institute for Social Research, Zagreb \& Friedrich-EbertStiftung, Zagreb;

[10] Mitev, P.-E. and Kovacheva, S. (2014), Young People in European Bulgaria: A Sociological Portrait 2014. Sofia: Friedrich-Ebert-Stiftung (FES), Sofia;

[11] Mitev, P.-E. and Kovacheva, S. (2014), Young People in European Bulgaria: A Sociological Portrait 2014 [SPSS dataset]. Sofia: FriedrichEbert-Stiftung (FES), Sofia;

[12] Orosová, O., Benka, J., Hricová, L. and Kulanová, M. (2018), Gender, Rootedness, Normative Beliefs and Emigration Intentions of Slovak University Students. International Migration, 56(4): 172-196;

[13] Plopeanu, A. P., Homocianu, D., Mihăilă, A., Crișan, E., Bodea, G., Bratu, R. D. andAirinei, D. (2018)., Exploring the Influence of Personal Motivations, Beliefs and Attitudes on Students' Post-Graduation Migration Intentions: Evidence from Three Major Romanian Universities. Applied Sciences, 8(11): 2-21;

[14] Roman, M. and Vasilescu, M. D. (2016), Explaining the Migration Intentions of Romanian Youth: Are Teenagers Different?. Romanian Statistical Review, 64(4): 69-86;

[15] Roman, M., Goschin, Z., Ileanu, B., Popa, A., Roman M. (2012), Emigratia romaneasca. Implicatii economice si demografice. ASE Publishing; Bucharest;

[16] Roman, M and Paraschiv, M.D. (2019), The Young Entrepreneurs of Europe and the Impact of International Mobility; Amfiteatru Economic, 21(13), Forthcoming November 2019;

DOI: $10.24818 / 18423264 / 54.1 .20 .06$ 
Monica Roman, ClaudiuVințe, Iris Alexe

[17] Roman, M. and Goschin, Z. (2011), Does Religion Matter? Exploring Economic Performance Differences among Romanian Emigrants; Journal for the Study of Religions and Ideologies, 10(30): 183-212;

[18] Sandu, D., Toth, G. and Tudor, E. (2018), The Nexus of MotivationExperience in the Migration Process of Young Romanians. Population, Space and Place, 24(1): e2114;

[19] Silva, M. and Neto, F. (1993), Psychosocial Predictors of Intent to Emigrate among Portuguese Adolescents. Journal of Applied Social Psychology, 23(16): 1285-1302;

[20] Stark, O. and Bloom, D. E. (1985), The New Economics of Labor Migration; The American Economic Review No. 75, Issue 2: 173-178;

[21] Stark, R. and W. S. Bainbridge (1987), A Theory of Religion. New York: Peter Lang Publishing;

[22] Tienda, M. and Taylor, L. (2007), New Frontiers, Uncertain Futures: Migrant Youth and Children of Migrants in a Globalized World; Princeton University;

[23] Umbreş, R, Sandu, D. and Stoica, C. A. (2014), Romanian Youth: Concerns, Aspirations, Attitudes and Life Style. Bucharest: Friedrich-EbertStiftung (FES), Bucharest;

[24] Umbreş, R, Sandu, D. and Stoica, C. A. (2014), Romanian Youth: Concerns, Aspirations, Attitudes and Life Style [SPSS dataset].Bucharest: Friedrich-Ebert-Stiftung (FES), Bucharest;

[25] Van Tubergen, F. (2006), Religious Affiliation and Attendance among Immigrants in Eight Western Countries: Individual and Contextual Effects. Journal for the Scientific Study of Religion, 45(1): 1-22;

[26] Van Tubergen, F. (2007), Religious Affiliation and Participation among Immigrants in a Secular Society: A Study of Immigrants in the Netherlands. Journal of ethnic and migration studies, 33(5): 747-765;

[27] Van Tubergen, F. and Sindradottir, J. I. (2011), The Religiosity of Immigrants in Europe: A Cross-national Study. Journal for the scientific study of religion, 50(2): 272-288;

[28] Žiga, J., Turčilo, L., Osmić, A., Bašić, S., Nedžma Džananović Miraščijan N., Kapidžić, D. and BrkićŠmigoc, J. (2015), Youth Study Bosnia and Herzegovina. Sarajevo: Friedrich-Ebert-Stiftung (FES), Sarajevo \& Faculty of Political Sciences Sarajevo;

[29] Žiga, J., Turčilo, L., Osmić, A., Bašić, S., Nedžma Džananović Miraščijan N., Kapidžić, D. and BrkičŠmigoc, J. (2015),Youth Study Bosnia and Herzegovina [SPSS dataset]. Sarajevo: Friedrich-Ebert-Stiftung (FES), Sarajevo \& Faculty of Political Sciences Sarajevo. 